\title{
Teaching Science Communication with Comics for Postgraduate Students
}

\author{
Olivier Robin ${ }^{1,2 *}$, Benoît Leblanc ${ }^{2,3}$ and Nancy Dumais ${ }^{2,3}$ \\ ${ }^{1}$ Départment de génie mécanique, Faculté de génie, Centre de Recherche Acoustique-Signal-Humain, Université de Sherbrooke, \\ Sherbrooke, QC, Canada, ${ }^{2}$ Centre compétences recherche+, Université de Sherbrooke, Sherbrooke, QC, Canada, \\ ${ }^{3}$ Département de biologie, Faculté des sciences, Université de Sherbrooke, Sherbrooke, QC, Canada
}

\section{OPEN ACCESS}

Edited by:

Anabela Carvalho,

University of Minho, Portugal

Reviewed by:

Sibo Chen,

Ryerson University, Canada

Richard Stoffle,

University of Arizona, United States

*Correspondence:

Olivier Robin

olivier.robin@usherbrooke.ca

Specialty section:

This article was submitted to

Science and Environmental

Communication,

a section of the journal

Frontiers in Communication

Received: 13 August 2021 Accepted: 17 September 2021

Published: 27 October 2021

Citation:

Robin O, Leblanc B and Dumais N (2021) Teaching Science

Communication with Comics for

Postgraduate Students.

Front. Commun. 6:758198.

doi: $10.3389 /$ fcomm.2021.758198
Data visualization and visual storytelling are increasingly common terms when institutions and scientists want to introduce people to their research and science through stories. Yet institutions mostly teach and train their scientists in the language of science and scientific journals, whereas research dissemination calls for other forms of communication. A new university course introducing such a new form of communication is proposed to postgraduate students at Université de Sherbrooke since January 2020. Its main objective is to help students develop their general interest and skills into science communication using comics as a working medium. While following a simple path, this course has generally led to results beyond initial expectations and large engagement from students. This study describes the general context and structure of the course, analyzes feedback from participants, presents some results, and summarizes lessons learned to help the diffusion of such a cross-disciplinary course.

Keywords: science communication, comics, postgraduate course, research dissemination, survey

\section{INTRODUCTION}

The great majority of scientific work is generated and communicated in the form of academic studies. Their yearly number has grown by a third since the beginning of the 21st century (Wilsdon et al., 2011) and reached an estimated value of 1,500,000 studies in 2015 (Unesco, 2015). This data deluge combined with the use of an arcane scientific language limits the impact and awareness of scientific discoveries to a narrow and specialized audience. It also raises questions about how a scientific study is currently presented and/or written and how scientific information can be communicated to diverse users in diverse ways (Sopinka et al., 2020). Increasingly, authors and publishers look to including non-traditional or additional research artifacts in publications so as to enhance interactions. The Acta Acustica journal recently launched "Audio Articles," a type of scientific article with embedded audio files in the PDF and HTML versions of the article. Reactive and interactive diagrams are also proposed in digital publishing, and graphical abstracts are becoming ubiquitous (Nature Chemistry, 2011).

In this context of a fast growing rate of science contents, the importance of science communication or research dissemination has increased for scientists and institutions to make research accessible to a wider audience but also to justify and stimulate funding (Ross-Hellauer et al., 2020). As the progress in different fields of science increasingly impact our understanding of the world and the way it is governed, the scientific community faces the challenge of communicating in efficient, clear, and engaging ways findings that are ever more complex. Considering how many variables may have to be considered to give an accurate view of any given field, this is however not 
always readily feasible. To wit, a 2016 study evaluating successive summaries by the Intergovernmental Panel on Climate Change Summaries for Policy Makers determined that this extremely important document remained of low readability despite considerable efforts (Barkemeyer et al., 2016). It is in this context of having to explain in more engaging ways concepts that are ever less easy to summarize that this project was instigated.

Ideal scientists should thus surely own a scientific language to interact with peers, but they should also develop abilities to communicate their science using compelling approaches such as different ways of telling stories. Indeed, storytelling/narratives are keywords that are often seen to describe a new practice for scientists to share their messages and findings in an engaging way (Flemming et al., 2018; Green et al., 2018; Hoffmann, 2020). Combining storytelling and science is sometimes discussed (Katz, 2013; Nature Methods, 2013) but is generally strongly advised to strengthen the interface between science and practice or between science and human beings (Krzywinski and Cairo, 2013; Arevalo et al., 2020; Jones and Crow, 2020; Muindi et al., 2020). To coin a phrase, data makes a story more credible and a story makes data less boring. Scientists can be portrayed as individuals and their motivation for research can be made relatable, and using a narrative style in an article can even positively impact its citation rate (Hillier et al., 2016). As a consequence, datadriven storytelling (Riche et al., 2018) is becoming a field in its own right and showcases interactive visualizations for science communication and education. Arts, educational games ${ }^{1}$, entertainment, imagination, and creativity are finally being included into teaching and learning approaches (Fahnert, 2019; Robin and Jaouen, 2019).

While having been the object of various criticisms (Wertham, 1954) and considered to be a subliterature for a long time, comics are now a legitimate art form, the ninth art, and an academic discipline $^{2}$ along with its specialized journals (few examples are: SANE journal: Sequential Art Narrative in Education; Journal of Graphic Novels and Comics; and The Comics Grid: Journal of Comics Scholarship). The fact that comics can be recognized as a legitimate form of academic publication has been demonstrated by several authors (Tisseron, 1975, 2009; Hureau, 2019; Sousanis, 2015). Comics are also considered as a full-fledged tool for disseminating and explaining science. Since the 1940s (Sones, 1944), comics have been generally seen as a valuable educational resource (Morel et al., 2019; Scavone et al., 2019; Kirtley et al., 2020) and science comics are now highly common (Schultz et al., 2009; Doxiadis et al., 2009; Hosler, 2013; Harder, 2015). Initiatives linking comics and science dissemination are mushrooming, including specialized websites ${ }^{3}$, cooperations ${ }^{4}$, and specialized meetings (Telling science-drawing science ${ }^{5}$ ). A

${ }^{1}$ https://explorabl.es/

${ }^{2}$ https://uqo.ca/emi, https://www.dundee.ac.uk/subjects/comics, https:// humanitiesliberalstudies.sfsu.edu/minor-comics-studies

${ }^{3}$ www.cartoonscience.org, https://www.datacomics.net/, https://www. graphicmedicine.org/

${ }^{4}$ https://www.stimuli-asso.com/

${ }^{5}$ https://sarabandes2016.sciencesconf.org/, https://tsds2019.sciencesconf.org/ comic book presenting the study of ten doctoral students and drawn by professionals cartoonists has been published for the five last editions of the annual French national science fair, reaching 80,000 copies in 2019. The European research council launched the "ERCcOMICS" initiative ${ }^{6}$ in 2014 that aims to circulate web comics promoting and explaining the achievements of 18 funded European research projects. More and more researchers advocate a larger use of comics in science (Farinella, 2018a,b,c; Scavone et al., 2019). One current trend is designated by the compound and new term "data comics" (Zhao et al., 2015; Bach et al., 2017; Wang et al., 2019a,b), which is praised for teaching data visualization and storytelling. Data comics can even help to humanize data for complex topics, typically related to health (McNicol, 2016; Alamalhodaei et al., 2020). Examples of graphical abstracts taking a comic-like form are becoming common (Caudron and Barral, 2013; Poisson et al., 2020). Creating comics is generally found to have a positive effect on students (Scavone et al., 2019) and comics-science workshops are more and more being evaluated for younger people (Tatalovic, 2009; Hosler and Boomer, 2011; Spiegel et al., 2013; de Hosson et al., 2018) or undergraduate students with a background in arts (Wang et al., 2019a). While guidelines or instructions for using this medium are now provided in the form of academic works (Friesen et al., 2018; McDermott et al., 2018), concrete initiatives to train graduate and postgraduate students to the use of comics in their research project remain scarce. All these initiatives are mostly held by external facilitators (de Hosson et al., 2018) and rarely by academic institutions.

While these observations show that comics are increasingly accepted as a valid, versatile, and engaging teaching resource, a significant hurdle in their widespread adoption is that relatively few people consider themselves to be sufficiently skilled artistically to consider producing their own; as with any field requiring a certain technical expertise, the first step might appear a little daunting. Here, we hypothesize that independent of a communicator's artistic skills or prior familiarity with comics, it is possible to devise a very focused course introducing science communicators to the basics of comics' grammar and to provide the technical skills required for even a neophyte to create comics of high quality.

Such a course has been devised as part of a global program to develop postgraduate students' transdisciplinary skills and has been offered since January 2020 at Université de Sherbrooke (EFD919-Communication scientifique par la bande dessinée/Science communication with comics, two academic credits). The course has currently been given on four distinct semesters. Since it is offered to any faculty of school of the university, participants profiles generally include a broad range of specialties (examples are engineering, natural sciences, health studies, biology, quantum mechanics, education, management, and law). While the course only includes $12 \mathrm{~h}$ of traditional teaching, the involvement of students and the results obtained generally exceed all expectations. Self-assessment of participants furthermore

${ }^{6} \mathrm{https} / /$ www.erccomics.com/ 
indicate a strong confirmation of our hypothesis, as a vast majority of responders reported an important or very important progress in their science communication skills and their confidence in using comics for science communication.

So as to share this experience, this communication describes the global methodology used for the course including setup, organization, and assignments. The benefits for participants in terms of science communication are analyzed using surveys. Lessons learned and future directions of this course are finally discussed, together with the possible uses for student's works.

\section{METHODS}

\subsection{Course Organization and Attendance}

The EFD919 course was given during Winter 2020 (W20), Summer 2020 (S20), Winter 2021 (W21), and Summer 2021 (S21) semesters. The three objectives of the course are 1) to train researchers to science communication, 2) to help them develop transdisciplinary skills, and 3) to generate concrete contents for science communication. Over the four teaching sessions, 42 students followed and passed the course. Among them, 45\% were women $(N=19), 55 \%$ were men $(N=23)$, and $74 \%$ were international students $(N=31)$.

The two teachers have proven skills in comics and science communication and have designed the course materials and organization. It is composed of four workshops of $3 \mathrm{~h}$ long each, and each spaced by approximately $3 \mathrm{wk}$ in order to allow sufficient time to elaborate and complete each intermediary work. The course was given in a classroom-based approach in Winter 2020 and Summer 2021 sessions and using an online teaching platform in Summer 2020 and Winter 2021 sessions given the COVID-19 pandemic. Even if this lowered the interactions level, the teachers did not notice a firm difference between classroom and online results.

For all the teaching sessions, the breakdown of the course was as follow:

- The first workshop integrates theoretical and general aspects concerning science communication, tools commonly used to disseminate content, and concrete examples of comics use within this area. The students are asked to write a summarized while popularized text concerning their research as a preliminary work (to be submitted prior the workshop, 300-400 words long). Each student introduces her/himself and has to summarize its research using popularized terms.

- The second workshop introduces the use of tools (free and open-source digital drawing software such as Krita, Medibang, or Inkscape). Comics grammar is also introduced (balloons, strips, and sketches), and examples of script breakdowns are discussed. Students briefly present their first breakdown of their scenario (popularized text transformed into a story) and then work in small groups (two to four people) to discuss/improve/elaborate their story. Teachers provide occasional interaction with groups for advices and suggestions.

- The third workshop first covers additional technical points like lettering, fonts, and balloons. Each participant presents his/her first drawn work and explains narrative choices to the group. This allows attendees to receive and provide comments and suggestions.

- The fourth workshop is fully devoted to the presentation of final works. Each comic is read publicly, and again all attendees are asked to receive and provide immediate reactions and comments.

Between workshops, the teachers provide individual feedback to all participants (concerning submitted intermediary works but also to answer to more specific questions, technical or general). To ensure inclusiveness, the workshops are systematically composed of several teaching and learning methods as well as varied educational content (lectures, multiple techniques, multimedia tools, and online videos). As pointed out in the course's breakdown, each work is evaluated and discussed by the teachers but also by the other participants during the workshops. Joint work and group feedback provide source FOR emulation and sharing of ideas and help verify understanding of key messages. Completion of the course requires the submission of a final drawn work to be used in any context (article, scientific presentation, interactions with the general public, and individual development, see two examples in the Results section). The advised type of work is two-page comics to have sufficient space to describe a subject but also to limit the amount of work to be done. Two-page comics represent approximately two-thirds of final works. Depending on the chosen support and subject, other typical outputs are posters, one-page comics, or more-than-two-page comics (some students even expanded their work up to eight to nine pages).

\subsection{Surveys}

Data were collected from three online surveys administered through the Moodle learning management system. Attendees received an initial notification about the surveys from the course teachers, and then two recruitment emails, each 5 days apart approximately. It is precised that a generally larger number of answers was obtained for the pre-course survey, since some students that initially registered for the course did not finally attend (especially for W21 session). All answers were nevertheless kept. The pre-course survey was designed to take respondents 5 min to complete and assessed each participant expectations and background for the course using close-ended questions. This survey was only administered after the course has been taught for the first time (i.e. after W20 session), and thus three teaching sessions are considered. The two post-course surveys were designed to take respondents $10 \mathrm{~min}$ to complete. The first post-course survey assessed the course impacts in terms of earned experience and knowledge, using close-ended questions. The second post-course survey aimed at collecting information concerning the use of comics and its components within the frame of science communication, and from the students 


\section{Workshop \#1}

EFD919 - Communication scientifique par la bande dessinée Silouane de Reboul - 26/01/2020

La simulation aéroacoustique

L'acoustique

L'acoustique est l'étude des ondes sonores, des vibrations de l'air qui se propagent jusqu'à nos oreilles. (les cordes et la table d'harmonie d'une guitare ou la membrane d'un haut-parleur), des objets qui frottent les uns contre les autres (une porte qui grince), des chocs (un marteau-piqueur), etc.

L'aéroacoustique

'aéroacoustique est létude du bruit produit par une source particulière : la turbulence dans un écoulement. Par exemple, quand le vent croise une éolienne sur son chemin, cet obstacle le perturbe et de nombreux tourbillons apparaissent autour des pales. Ces petits mouvements de l'air sont responsables du bruit produit.

On peut citer de très nombreux autres bruits d'origine aérodynamiques: celui de l'air mis en mouvement par les voitures sur l'autoroute, celui des réacteurs des avions, des pales des hélicoptères. des drones, mais aussi les battements d'ailes des oiseaux, le sifflement du vent dans les arbres, etc.

La simulation numérique

pour connaitre un bruit, on dispose principalement de deux movens:

1) On peut utiliser un micro pour le mesurer.

pour cela, les scientifiques partent les lois de la sont difficiles à résoudre, Ia simulation numérique est ''ut tilisation d'al erorithmes pour trouver des solutions approchées à ces équations

A quoi ça sert ?

Imaginez un fabricant de voiture, qui souhaite que le bruit à lintérieur de ses véhicules soit suffisamment bas pour que les utilisateurs puissent discuter entre eux sans crier, même à $150 \mathrm{~km} / \mathrm{h}$ sur l'autoroute. Ce constructeur a donc besoin de connaitre le bruit de sa voiture. On a vu précédemment qu'il y avait deux méthodes pour cela :

1) II construit sa voiture, la fait rouler, et mesure le bruit à l'oreille du conducteur ou des passagers

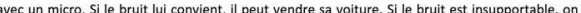
met la voiture à la casse, les plans à la poubelle les ingénieurs au chômage, et on recommence. 2) II utilise la simulation numérique pour prédire le bruit de sa future voiture avant même qu'elle ne soit construite. Si le bruit ne convient pas, il suffit de reprendre les plans. Ceci lui permet d’économiser du temps, de l'argent, et des ressources naturelle.

\section{Workshop \#3}

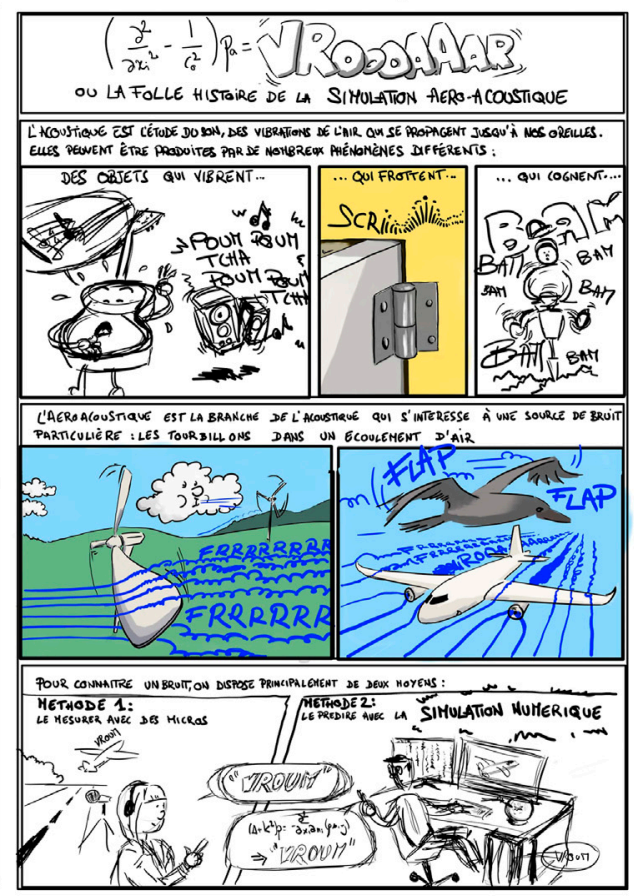

\section{Workshop \#2}

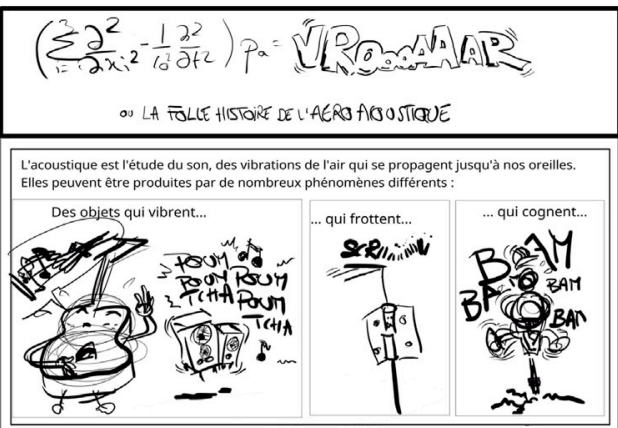

L'aéroacoustique est la branche de l'acoustique qui sintéresse à une source particulière: les tourbillons dans un écoulement d'air.

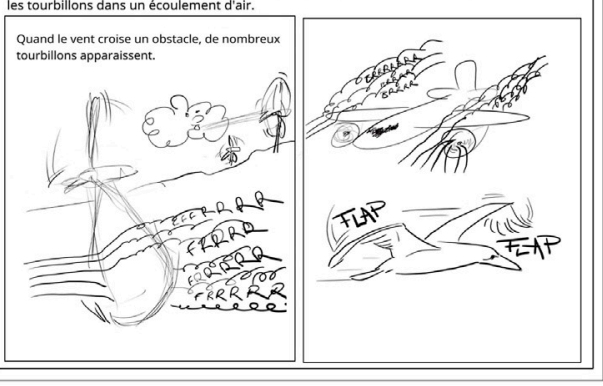

Workshop \#4

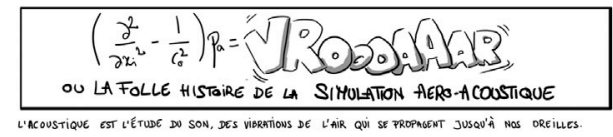

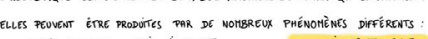

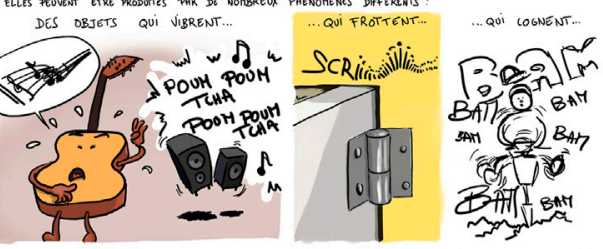

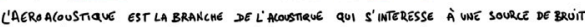
PARTCULEE RE : LES TOURBILL ONS DAUS UN ECOULEMENT J'AAI A
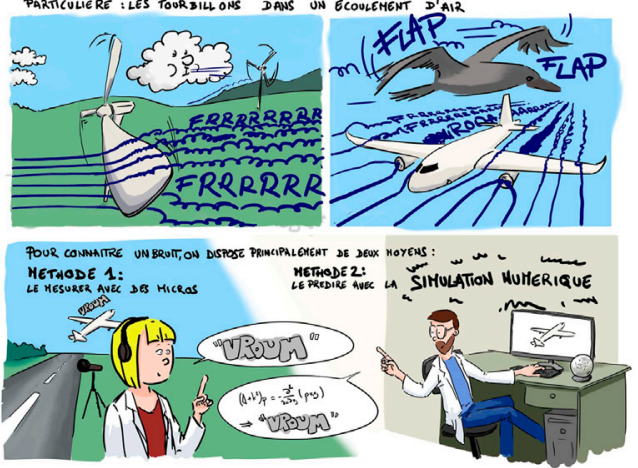

FIGURE 1 | First example of the course outcomes: Workshop \#1: initial popularized text; Workshop \#2: first graphical breakdown; Workshop \#3: second graphical breakdown; Workshop \#4: final colorized work (Silouane de Reboul, La simulation aéroacoustique - Aeroacoustics simulation).

standpoint (how they used comics' features and elements in their work?). The questions and possible answers for each survey and corresponding results are reported in the following section. The pretest survey return rate was $95 \%$ while the two post test surveys return rate was approximately $80 \%$ (S21 session had the lowest response rate). 


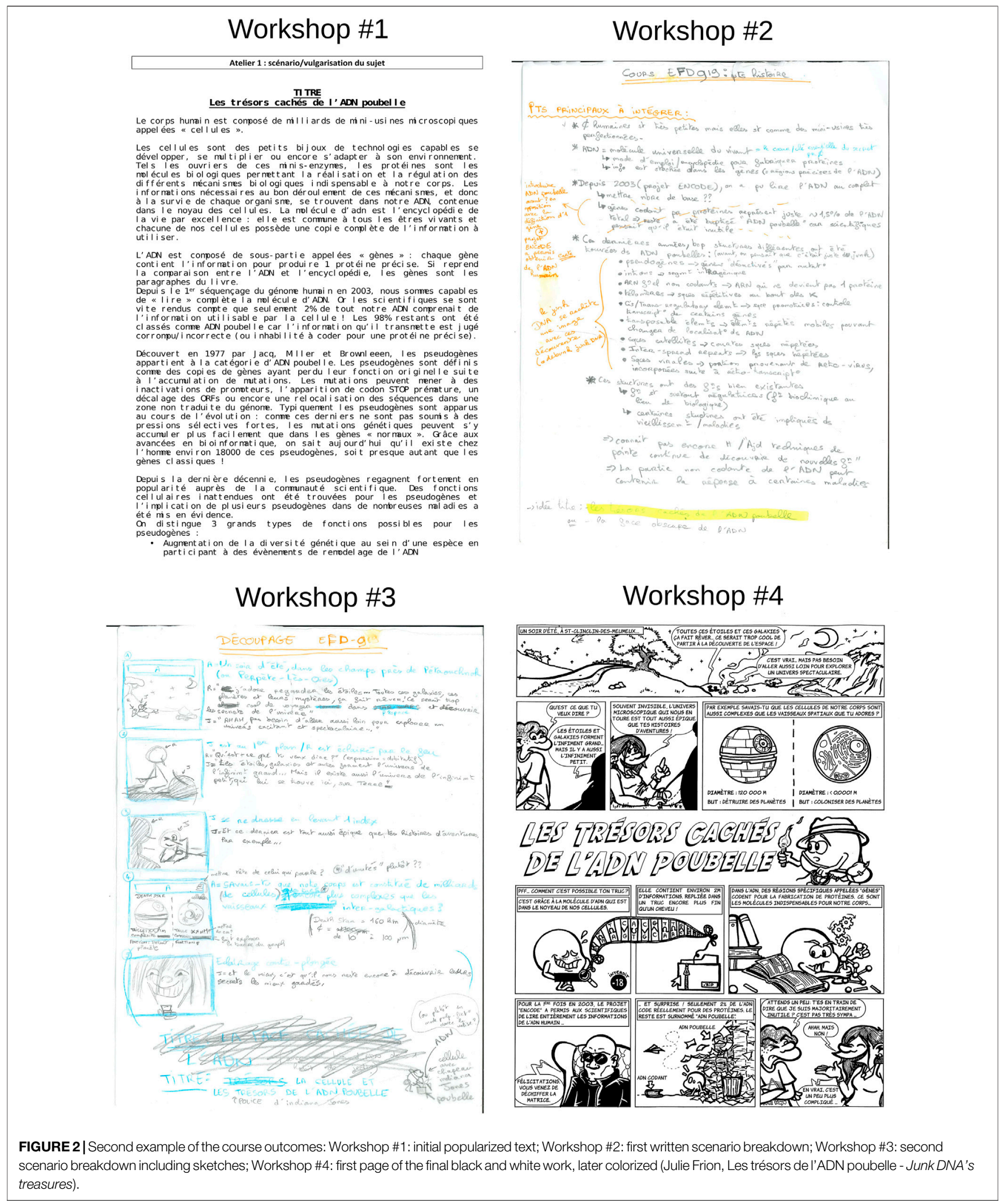


TABLE 1 | Results of the pre-course survey over three teaching sessions.

\begin{tabular}{|c|c|c|c|c|c|}
\hline \multirow{2}{*}{$\frac{\text { Question } 1}{\text { Possible answers }}$} & \multicolumn{5}{|c|}{ How would you qualify your general knowledge of science communication? } \\
\hline & Very low & Low & Median & High & Very High \\
\hline $\mathrm{S} 20(N=11)$ & 0 & 1 & 5 & 4 & 1 \\
\hline W21 $(N=17)$ & 1 & 4 & 8 & 4 & 0 \\
\hline $\mathrm{S} 21(N=9)$ & 0 & 1 & 7 & 1 & 0 \\
\hline Overall (in $\%, N=37$ ) & 3 & 16 & 54 & 14 & 3 \\
\hline Question 2 & \multicolumn{5}{|c|}{ What is your knowledge level concerning the use of comics for sci. com.? } \\
\hline Possible answers & Very low & Low & Median & High & Very High \\
\hline $\mathrm{S} 20(N=11)$ & 6 & 4 & 1 & 0 & 0 \\
\hline W21 $(N=17)$ & 7 & 8 & 2 & 0 & 0 \\
\hline $\mathrm{S} 21(N=9)$ & 4 & 5 & 0 & 0 & 0 \\
\hline Overall (in \%, $N=37$ ) & 46 & 46 & 8 & 0 & 0 \\
\hline Question 3 & & is your $\mathrm{cc}$ & ice level concerning & lics for & \\
\hline Possible answers & Very low & Low & Median & High & Very High \\
\hline $\mathrm{S} 20(N=11)$ & 0 & 3 & 2 & 5 & 1 \\
\hline W21 $(N=17)$ & 0 & 1 & 3 & 8 & 5 \\
\hline $\mathrm{S} 21(N=9)$ & 0 & 0 & 3 & 5 & 1 \\
\hline Overall (in \%, with $N=37$ ) & 0 & 11 & 19 & 49 & 19 \\
\hline Question 4 & & Do you $t$ & at the use of comic & mmunic & \\
\hline Possible answers & Common & & Not common & & of it before \\
\hline $\mathrm{S} 20(N=11)$ & 3 & & 6 & & \\
\hline W21 $(N=17)$ & 2 & & 12 & & \\
\hline $\mathrm{S} 21(N=9)$ & 0 & & 7 & & \\
\hline Overall (in \%, N=37) & 14 & & 68 & & \\
\hline Question 5 & & & $\begin{array}{r}\text { Do you have some } \\
\text { that you thin }\end{array}$ & $\begin{array}{l}\text { e (drawi } \\
\text { ke use }\end{array}$ & $\begin{array}{l}\text { g software) } \\
\text { urse? }\end{array}$ \\
\hline Possible answers & & & Yes & & No \\
\hline $\mathrm{S} 20(N=11)$ & & & 3 & & 8 \\
\hline W21 $(N=17)$ & & & 8 & & 8 \\
\hline $\mathrm{S} 21(N=9)$ & & & 5 & & 4 \\
\hline Overall (in \%, N = 37) & & & 43 & & 57 \\
\hline
\end{tabular}

Sessional results are given in terms of number of response per answer, while overall results are converted in percentage.

\section{RESULTS}

\subsection{Two Examples of Student Works}

Figures 1, 2 illustrate two typical work progressions as a function of the workshop number. Both students had hand sketching experience but were novices concerning comics and its design.

The compact nature of a short comic demands that the author first identify the core message that is to be carried out. This is done in a first rough script, in which elements will be considered and either retained or set aside, depending on how necessary they are, how they affect the flow of the story, and how much leeway the storytelling approach allows (see Figure 1 - Workshop \#1 and Figure 2 - Workshops \#1-3). Graphical elements can already be considered at this stage. In the second step (Figure 1, Workshop $\# 2$ ), a rough draft allows the author to set the pace and tone of the story, determine what information can be fitted on the page, and see how it can be best integrated in the story line. This step usually leads to several alternate versions. The following steps (Figure 1, Workshop \#3-4, Figure 2, Workshop \#4) actualize the ideas considered in the preceding step, with final adjustments being made to enhance the story's pace and its readability. Fonts are adjusted, and complex words are replaced by synonyms or simpler wordings. Graphical analogies and metaphors are nearly always embedded into the work (Onomatopoeia in Figure 1-Workshop \#three to four, the Star Wars death star vs. our body cells to illustrate respective diameters and objectives in Figure 2-Workshop \#4).

It can be precised that even if all works start with a popularized text and end with a piece of comic-based work, the followed path between these two points can vary between participants. This heavily depends on the creative part of the process, and the main idea of the story can be either found very soon or might take a longer time to be identified. It is not unusual that students do not present a first breakdown for the second workshop because they 
TABLE 2 | Results of the post-course survey over four teaching sessions.

Question 1

After this course, how would you qualify your knowledge level progression concerning science communication?

\begin{tabular}{|c|c|c|c|c|c|}
\hline Possible answers & Very limited & Limited & Average & Important & Very important \\
\hline W20 (N = 12) & 0 & 1 & 2 & 8 & 1 \\
\hline $\mathrm{S} 20(N=10)$ & 0 & 0 & 4 & 5 & 1 \\
\hline W21 $(N=7)$ & 0 & 0 & 2 & 5 & 0 \\
\hline $\mathrm{S} 21(N=5)$ & 0 & 0 & 2 & 2 & 1 \\
\hline Overall (in \%, N=34) & 0 & 3 & 30 & 59 & 9 \\
\hline
\end{tabular}

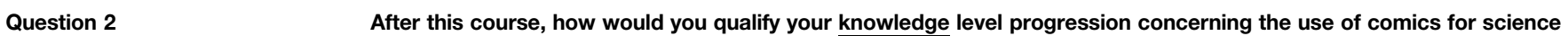
communication?

\begin{tabular}{|c|c|c|c|c|c|}
\hline Possible answers & Very limited & Limited & Average & Important & Very important \\
\hline W20 $(N=12)$ & 0 & 0 & 1 & 7 & 4 \\
\hline $\mathrm{S} 20(N=10)$ & 0 & 0 & 0 & 5 & 5 \\
\hline W21 $(N=7)$ & 0 & 0 & 0 & 7 & 0 \\
\hline $\mathrm{S} 21(N=5)$ & 0 & 0 & 0 & 3 & 2 \\
\hline Overall (in \%, $N=34$ ) & 0 & 0 & 3 & 65 & 32 \\
\hline
\end{tabular}

Question 3

After this course, how would you qualify your confidence level progression concerning the use of comics for science communication?

\begin{tabular}{lcccc}
\hline Possible answers & Very limited & Limited & Average & Very important \\
W20 $(N=12)$ & 0 & 0 & 2 & 3 \\
S20 $(N=10)$ & 0 & 0 & 2 & 3 \\
W21 $(N=7)$ & 0 & 0 & 0 & 5 \\
S21 $(N=5)$ & 0 & 0 & 0 & 3 \\
Overall (in \%, $N=34)$ & 0 & 0 & 12 & 53
\end{tabular}

Question 4

Whatever your prior knowledge in arts or media, would you say that during this course, this knowledge has?

Possible answers

W20 $(N=12)$

$\mathrm{S} 20(N=10)$

W21 $(N=7)$

S21 $(N=5)$

Overall (in \%, $N=34$ )
Largely improved

10

9

5

79
Barely improved

$\begin{array}{ll}0 & 2 \\ 9 & 1 \\ 3 & 2 \\ 9 & 2 \\ 9 & 21\end{array}$

Sessional results are given in terms of number of response per answer, while overall results are converted in percentage.

did not find their starting point. Presentations from other students and group works in Worshop \#2 usually help triggering this process.

\subsection{Pre-course Survey}

The results from this survey are provided in Table $\mathbf{1}$. The general knowledge level concerning science communication, evaluated in Question 1, is nearly normally distributed around the median answer, with $54 \%$ of answers. It appears from the results of Question 2 that the great majority of attendants consider that they have an overall very low or low level of knowledge concerning the use of comics for science communication $(46 \%$ "Very low" and 46\% "Low"). Nevertheless, the answer to Question 3 reveal that this is not necessary linked to a lack of confidence, with $68 \%$ of the students reporting a "High" or "Very high" confidence level. Overall, the distribution of answers (from "Very low" to "Very high") concerning knowledge and confidence are nearly opposite. According to Question 4, 68\% of the attendants think that science communication using comics is not common, and $20 \%$ even report having never thought of it before. This shows that even if the use of comics is strongly developing as pointed out in the Introduction section, this use is not well known by postgraduate students. Finally, the results of Question 5 concerning students' prior skills for this course show that a little more than half of students (57\%) could be considered for beginners. From the students point-of-view, comic-based science communication is thus perceived as unknown as its tools and methods, but it nevertheless gives them confidence into its use.

\subsection{First Post-course Survey}

This survey's results are provided in Table 2. According to the results of this survey, the progression of general knowledge of science communication is mostly considered "Important" with $59 \%$ of the answers. Nearly all students estimate that their knowledge level concerning science communication has largely improved (65\% and 32\% for "Important" and "Very important" progressions, respectively). Compared with the 
TABLE 3 | Results of the post-course survey over four teaching sessions.

Question 1

What is the main function of the characters that you designed?

Possible answers They directly represent the subject of my research (i.e. an animal for zoology)

They serve as speakers to describe my work

W20 $(N=11)$

$\mathrm{S} 20(N=10)$

W21 $(N=8)$

$\mathrm{S} 21(N=4)$

Overall (in $\%, N=33$ )
7

6

4

Question 2

How did you manage scientific information in your work?

Possible answers

I always clearly transcribed scientific information

I had to modify it to convey my message

W20 $(N=11)$

$\mathrm{S} 20(N=10)$

W21 $(N=8)$

S21 $(N=4)$

Overall (in \%, $N=33$ )

$\begin{array}{cc}8 & 3 \\ 7 & 3 \\ 4 & 3 \\ 3 & 4 \\ 67 & 33\end{array}$

\section{Question 3}

Would you say that you wrote?

Possible answers

A story that precisely describes your research

A precise description of your research, but not a story

W20 $(N=11)$

\section{A generic story}

S20 $(N=10)$

W21 $(N=8)$

S21 $(N=4)$

Overall (in \%, N=33)

Question 4

2
3
5
1
33

3

3

33

To which kind of audience do you think this work is suited (choose all the answers that apply)?

Possible answers, multiple

choices are accepted

University-level, close

University-level, any

research area

The general

public, all ages

The general public, mostly young people

The general public, mostly adults

W20

S20

W21

S21

Overall (in \%, N=55)

$\begin{array}{cc}4 & 5 \\ 3 & 5 \\ 3 & 7 \\ 0 & 2 \\ 18 & 35\end{array}$

4
1
2
1
15

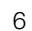

5

7

5

Sessional results are given in terms of number of response per answer, while overall results are converted in percentage.

reported low level at the beginning of the course, this indicator illustrates a large impact on this considered criterion. Another interesting point is that even if the confidence level was already high before following the course, the respondents report that they nevertheless have a large progression concerning this point. Finally, a global increase in terms of knowledge in arts and media is noted, with only $21 \%$ answers reporting a bare improvement in this domain. These results indicate that two of the objectives of such course are achieved, that is, developing transdisciplinary skills and training researchers to science communication. Several students underlined that they had large interest in arts before starting higher education (and being involved into more specialized and intensive teachings) and valued the possibility of combining their interests in different domains.

\subsection{Second Post-course Survey}

This survey aimed at analyzing from the student's standpoint on how they used comics' features and elements in their work and how they foresee the use of this work. The corresponding results are provided in Table 3. The results obtained for Question 1 show that the students choice of a character directly linked to their research or of a character that would be a simple speaker to describe their research is nearly split half. The analysis of students work by the teachers reveals that the choice of a human-like or non-human character was also nearly parted in half. It is as much the object of science as the person doing this science that are thus used to illustrate a research. Answers to Questions 2 and 3 provide interesting information concerning science and its storytelling. The scientific information was deemed clearly transcribed in their work by $67 \%$ of the students, and the remaining $33 \%$ had to modify it to convey their message. The "Storytelling" term for the use of comics in science communication seems appropriate with only $12 \%$ of works being considered a precise description of a research, but not a story (see Question 3). The answer to Question 4 indicates the general public as the mostly contemplated audience for the work made during the course, with an orientation towards adults. The research area seems not firmly influential on potential university-level readers. Nevertheless, these numbers are weighted by their answer's occurrence since multiple choices were accepted so that they might be biased.

When students were asked if they intended to reuse the work they did during the course and if yes, "In which context?", the 
answer was unanimous: $100 \%$ of the 33 respondents were willing to reuse this work. The answers to the open-ended question "In which context?" were as follows (ordered in decreasing order of number of occurrences): in a conference presentation, for science communication opportunities or projects, during my $\mathrm{PhD}$ defense, in my thesis, to explain my thesis subject to relatives, as a poster for visitors in my lab, for a journal study (supplementary material or graphical abstract), knowledge transfer with partners of a project. This corresponds to the validation of the third objective of the course, that is, to generate concrete contents for science communication. Another open-ended question asked the attendees to provide an adjective to qualify the general tone of their work. The three most cited adjectives were (in decreasing order): humorous, didactic, and documentary. Finally, the last openended question was the following: "Would you recommend this course to doctoral students and postdoctoral fellows? If yes, provide a reason why." The answer was positive for all the respondents, and five reasons why are reported below:

- "Because it allows you to take another look at your doctoral work and to better explain complex notions to people not initiated in the subject. The exchange with other doctoral students is also very beneficial,"

- "This course allows science popularization to be seen in a whole new light,"

- "Because it progresses from an idea to popularize until its complete production,"

- "We think outside the box and the teachers, as well as the exchange with other students, open our horizons. The course has implications for our communication skills beyond the comics-based style,"

- "I would strongly recommend this training to anyone interested in science communication, because it allows you to approach and understand science from another point of view, surely fun but also effective in conveying a message."

\section{CONCLUSION AND PERSPECTIVES}

This study described a university course which main objective is to help postgraduate students develop their general interest and skills into science communication using comics as a working medium. All testimonies and survey results confirm the interest of such a science communication course that encompasses several domains. The discovery of other research areas and non-specialist point of views were highly appreciated and stimulated motivation in the course. It appears that comicbased science communication is not well known, but accessible. Within a teaching session, it is possible to obtain high quality works that can be used for various purposes. The participants can appreciate a complete science communication process, from an in-depth work to transform a scientific language to an adapted language until a concrete and tangible achievement. Even if science communication and its outcomes remain difficult to evaluate, as pointed out by Fischhoff (2019), the significant engagement that is promoted by this course allows us to reach effective and concrete results.
One of the stumbling blocks most often mentioned by participants was their initial self-appraised lack of artistic skills or lack of familiarity with traditional or computerized graphic tools, something that is reflected by the data in Table 1. Although proper training with classical tools like pencil, pen, and brush would require an extended period, it is quite feasible to guide students through the use of computer-based techniques, including the use of programs especially conceived to draw comics, even with no artistic prior training whatsoever- in just a few hours. This conclusion is shared by Scavone et al. (2019) that point out that it is not only experienced illustrators who can make comic strips, concept cartoons, or even short comic books. The same authors underline that "Even if one does not know how to draw, this should not be a barrier to communicate (...) through the creation of comics." This is indeed the case in practice according to the presented results and surveys. It is nevertheless underlined that overcoming beliefs of students (and educators) regarding the role of informal reading materials in science education should be systematically considered, since it was identified as a challenge that participants encountered in using comics in Matuk et al. (2021).

A series of short videos detailing and demonstrating such resources is already used in the class, and it would doubtless be beneficial to add a few more, particularly ones focusing on technical problems encountered by students of the class's first cohorts. From the teacher's point of view, this course concept can be easily adapted to teach other levels like senior undergraduates provided educators have sufficient knowledge concerning comics and science to answer (quite) miscellaneous questions and support students. A growing number of articles or reports underline the positive effect that creating comics have on student learning and teaching, with examples in various domains like engineering (Barros et al., 2017), management (Barbosa et al., 2017), or operations research (Zamora et al., 2021). Some resources that provide step-by-step instructions for the conceptualization and design of comics that are based on scientific publications are readily available (Friesen et al., 2018; McDermott et al., 2018).

One point that could be also included in future works is crosscultural communication. Indeed, all participants could be here considered of the same or close culture so that chosen comic images and language will generally increase communication, which could be further studied if the course was taught in various contexts and for various communities including indigenous ones. Nevertheless, a combination of text and images carrying information (or telling a story) is an approach that was developed by several cultures independently and observed as early as 13th century BCE (Egypt's Book of the Dead), ancient versions of the Persian epic poem Shahnameh (see the 14th century Demotte Shahnameh, for example), or 11th century Europe (the Bayeux tapestry). The drive to represent reality in a graphic format seems to be a cross-cultural phenomenon, and widespread enough to have a nearly global appeal.

In the coming courses, starting in Winter 2022 session, new surveys will be also designed to refine assessment of fostered qualities and support continuous improvement of the course. Following the two first sessions, a series of workshops has been 
opened to a larger community (undergraduate and graduate students, as well as professors) thanks to a science communication grant. One of the most exciting perspectives is the current setup of a book gathering a series of comic-based works. This book will include works conducted within the enlarged community workshops, some of the works produced during the EFD919 course and comics made by professional comics writers on the basis of winning texts from the science popularization contest at Université de Sherbrooke. This book will serve as a unique medium to disseminate science and for science teaching (secondary schools and colleges are especially targeted). Indeed, the question of how produced comics can be further used to support teaching at various levels and the evaluation of their impact will be also considered in future works. Matuk et al. (2021) observed "how the use of a comic book series enabled educators to incorporate multiple literacies and disciplinary lenses into their lessons." They noted that the use of comics helps to increase the diversity of students likely to engage with science, to bridge science and students personal experience, and finally promote engagement, equity, and diversity. The work carried out during all workshops will thus be valued with an effective transfer of scientific knowledge to the university community and the general public.

\section{DATA AVAILABILITY STATEMENT}

The raw data supporting the conclusions of this article will be made available by the authors, without undue reservation.

\section{ETHICS STATEMENT}

Ethical review and approval was not required for the study on human participants in accordance with the local legislation and institutional requirements. Written informed consent for

\section{REFERENCES}

Alamalhodaei, A., Alberda, A., and Feigenbaum, A. (2020). "Humanizing Data Through 'Data Comics': An Introduction to Graphic Medicine and Graphic Social Science," in Data Visualization in Society. Editors M. Engebretsen and H. Kennedy (Amsterdam: Amsterdam University Press), 201-213. doi:10.5117/ 9789463722902_ch21

Arevalo, V. J. C., Verbrugge, L., Sools, A., Brugnach, M., Wolterink, R., van Denderen, R. P., et al. (2020). Storylines for Practice: A Visual Storytelling Approach to Strengthen the Science-Practice Interface. Sustain. Sci. 10, 1013. doi:10.1007/s11625-020-00793-y

Bach, B., Riche, N. H., Carpendale, S., and Pfister, H. (2017). The Emerging Genre of Data Comics. IEEE Comput. Grap. Appl. 37, 6-13. doi:10.1109/ mcg.2017.33

Barbosa, A., Tavares, G., and Kruta, A. (2017). The Comics as Teaching Strategy in Learning of Students in an Undergraduate Management Program. RAM Rev. Adm. Mackenzie 18, 40-65. doi:10.1590/1678-69712017/administracao.v18n6p224-224

Barkemeyer, R., Dessai, S., Monge-Sanz, B., Renzi, B. G., and Napolitano, G. (2016). Linguistic Analysis of Ipcc Summaries for Policymakers and Associated Coverage. Nat. Clim Change 6, 311-316. doi:10.1038/ nclimate 2824 participation was not required for this study in accordance with the national legislation and the institutional requirements. Written informed consent was obtained from the individual(s) for the publication of any potentially identifiable images or data included in this article.

\section{AUTHOR CONTRIBUTIONS}

OR wrote the original draft of this article, setup the surveys, and extracted corresponding data. OR and BL equally implemented the course contents and taught the course. ND supported the course setup as an initial pilot course. All authors equally contributed to the review and editing of the submitted version of this article and approved it.

\section{FUNDING}

The printing of a book that will include some works arising from this course is made possible through a Science Communication Skills grant. The extension of the presented workshops to undergraduate students, MSc students, and professors was also achieved through this grant. We acknowledge the support of the Natural Sciences and Engineering Research Council of Canada (NSERC). Nous remercions le Conseil de recherches en sciences naturelles et en génie du Canada (CRSNG) de son soutien. The financial support of Université de Sherbrooke through the Centre compétences recherche $e^{+}$is also acknowledged.

\section{ACKNOWLEDGMENTS}

Silouane de Reboul and Julie Frion are thanked for sharing their intermediate and final works that are given in Figures 1, 2, respectively. Fatima Bousadra is acknowledged for her helpful suggestions concerning the surveys.

Barros, D. M. R., Begosso, L. R., Fabri, J. A., and L'Erario, A. (2017). “The Use of Comic Strips in the Teaching of Software Engineering," in 2017 IEEE Frontiers in Education Conference (FIE), Indianapolis, IN, December 14, 2017 (IEEE), 1-8. doi:10.1109/FIE.2017.8190537

Caudron, F., and Barral, Y. (2013). A Super-assembly of Whi3 Encodes Memory of Deceptive Encounters by Single Cells during Yeast Courtship. Cell 155, 1244-1257. doi:10.1016/j.cell.2013.10.046

de Hosson, C., Bordenave, L., Daures, P.-L., Décamp, N., Hache, C., Guediri, N., et al. (2018). Communicating Science Through the Comics Science Workshops: the Sarabandes Research Project. JCOM 17, 10127-10134. doi:10.22323/2.17020203

Doxiadis, A., Papadimitriou, C., Papadatos, A., and Donna, A. D. (2009). Logicomix: An Epic Search for Truth. New York: Bloomsbury Publishing.

Fahnert, B. (2019). Be Prepared - Learning for the Future. FEMS Microbiol. Lett. 366, fnz200. doi:10.1093/femsle/fnz200

Farinella, M. (2018a). Of Microscopes and Metaphors: Visual Analogy as a Scientific Tool. The comics grid: J. comics scholarship 8, 1-16. doi:10.16995/cg.130

Farinella, M. (2018b). The Potential of Comics in Science Communication. JCOM 17, 1-17. doi:10.22323/2.17010401

Farinella, M. (2018c). Science Comics' Super Powers. Amer. Scientist 106, 218. doi:10.1511/2018.106.4.218

Fischhoff, B. (2019). Evaluating Science Communication. Proc. Natl. Acad. Sci. USA 116, 7670-7675. doi:10.1073/pnas. 1805863115 
Flemming, D., Cress, U., Kimmig, S., Brandt, M., and Kimmerle, J. (2018). Emotionalization in Science Communication: The Impact of Narratives and Visual Representation on Knowledge Gain and Risk Perception. Front. Comm. 3, 1-9. doi:10.3389/fcomm.2018.00003

Friesen, J., Van Stan, J., II, and Elleuche, S. (2018). Communicating Science Through Comics: A Method. Publications 6, 38-10. doi:10.3390/publications6030038

Green, S. J., Grorud-Colvert, K., and Mannix, H. (2018). Uniting Science and Stories: Perspectives on the Value of Storytelling for Communicating Science. FACETS 3, 164-173. doi:10.1139/facets-2016-0079

Harder, J. (2015). Alpha. London: Knockabout.

Hillier, A., Kelly, R. P., and Klinger, T. (2016). Narrative Style Influences Citation Frequency in Climate Change Science. PLos One 11, e0167983. doi:10.1371/ journal.pone. 0167983

Hoffmann, R. (2020). The Tensions of Scientific Storytelling. Am. scientist 102, 250-253.

Hosler, J., and Boomer, K. B. (2011). Are Comic Books an Effective Way to Engage Nonmajors in Learning and Appreciating Science?1. Life Sci. Educ. 10, 309-317. doi:10.1187/cbe.10-07-0090

Hosler, J. (2013). Clan Apis. Scotts Valley, CA: CreateSpace Independent Publishing Platform.

Hureau, M. (2019). La Bande Dessinée Comme Forme Académique. belphegor 17, 1-24. doi:10.4000/belphegor.1882

Jones, M. D., and Crow, D. A. (2017). How Can We Use the 'Science of Stories' to Produce Persuasive Scientific Stories? Palgrave Commun. 3, 1-9. doi:10.1057/ s41599-017-0047-7

Katz, Y. (2013). Against Storytelling of Scientific Results. Nat. Methods 10, 1045. doi:10.1038/nmeth.2699

Krzywinski, M., and Cairo, A. (2013). Storytelling. Nat. Methods 10, 687. doi:10.1038/nmeth. 2571

Matuk, C., Hurwich, T., Spiegel, A., and Diamond, J. (2021). How Do Teachers Use Comics to Promote Engagement, Equity, and Diversity in Science Classrooms? Res. Sci. Educ. 51, 685-732. doi:10.1007/s11165-018-9814-8

McDermott, J. E., Partridge, M., and Bromberg, Y. (2018). Ten Simple Rules for Drawing Scientific Comics. Plos Comput. Biol. 14, e1005845. doi:10.1371/ journal.pcbi.1005845

McNicol, S. (2016). The Potential of Educational Comics as a Health Information Medium. Health Inf. Libraries J. 34, 20-31. doi:10.1111/hir.12145

Morel, M., Peruzzo, N., Rodriguez Juele, A., and Amarelle, V. (2019). Comics as an Educational Resource to Teach Microbiology in the Classroom. J. Microbiol. Biol. Educ. 20, 1-4. doi:10.1128/jmbe.v20i1.1681

Muindi, F. J., Ramachandran, L., and Tsai, J. W. (2020). Human Narratives in Science: The Power of Storytelling. Trends Molecular Medicine 26, 249-251. doi:10.1016/j.molmed.2019.12.001

Nature Chemistry (2011). The Art of Abstracts. Nat. Chem. 3, 571. doi:10.1038/ nchem.1109

Nature Methods (2013). Should Scientists Tell Stories? Nat. Methods 10, 1037. doi: $10.1038 /$ nmeth. 2726

N. H. Riche, C. Hurter, N. Diakopoulos, and S. Carpendale (Editors) (2018). DataDriven Storytelling (New York: A K Peters/CRC Press). doi:10.1201/9781315281575

Poisson, Y., Fiesta-Bianchet, M., and Pelletier, F. (2020). Testing the Importance of Harvest Refuges for Phenotypic rescue of Trophy-Hunted Populations. J. Appl. Ecol. 57, 526-535. doi:10.1111/1365-2664.13562

Robin, O., and Jaouen, L. (2019). "Teaching/learning Acoustics through Entertainment?," in 26th International Congress on Sound and Vibration, Montreal, July 7-11, 2019, 1-8.

Ross-Hellauer, T., Tennant, J. P., Banelyte, V., Gorogh, E., Luzi, D., Kraker, P., et al. (2020). Ten Simple Rules for Innovative Dissemination of Research. Plos Comput. Biol. 16, e1007704. doi:10.1371/journal.pcbi.1007704

Scavone, P., Carrasco, V., Umpiérrez, A., Morel, M., Arredondo, D., and Amarelle, V. (2019). Microbiology Can Be Comic. FEMS Microbiol. Lett. 366, fnz171. doi:10.1093/femsle/fnz171
Schultz, M., Cannon, Z., and Cannon, K. (2009). The Stuff of Life: A Graphic Guide to Genetics and DNA. 1st Edn. New York: Hill and Wang.

S. Kirtley, A. Garcia, and P. Carlson (Editors) (2020). Woth Great Power Comes Great Pedagogy - Teaching, Learning and Comics. (Jackson: University Press of Mississippi).

Sones, W. D. (1944). The Comics and Instructional Method. J. Educ. Sociol. 18, 232-240. doi:10.2307/2262696

Sopinka, N., Coristine, L., DeRosa, M., Rochman, C., Owens, B., and Cooke, S. (2020). Envisioning the Scientific Paper of the Future. FACETS 5, 1-16. doi:10.1139/facets-2019-0012

Sousanis, N. (2015). Unflattening. Cambridge: Harvard University Press.

Spiegel, A. N., McQuillan, J., Halpin, P., Matuk, C., and Diamond, J. (2013). Engaging Teenagers with Science Through Comics. Res. Sci. Educ. 43, 2309-2326. doi:10.1007/s11165-013-9358-x

Tatalovic, M. (2009). Science Comics as Tools for Science Education and Communication: A Brief, Exploratory Study. JCOM 8, 1-17. doi:10.22323/ 2.08040202

Tisseron, S. (1975). Contribution à l'utilisation de la bande-dessinée comme instrument pédagogique : une tentative graphique sur l'histoire de la psychiatrie. PhD thesis. 1-88.

Tisseron, S. (2009). Passer sa thèse en bandes dessinées. c'est possible et c'est nécessaire! [defending a doctoral thesis using comics. possible and needed !]. Sociétés 106, 9-13. doi:10.3917/soc.106.0009

Unesco (2015). UNESCO Science Report: Towards 2030 by United Nations Educational, Scientific and Cultural Organization (UNESCO). Paris: UNESCO Publishing.

Wang, Z., Dingwall, H., and Bach, B. (2019a). "Teaching Data Visualization and Storytelling with Data Comic Workshops," in CHI 2019, May 4-9, 2019 (Glasgow, UK), 1-9. doi:10.1145/3290607.3299043

Wang, Z., Wang, S., Farinella, M., Murray-Rust, D., Riche, N., and Bach, B. (2019b). "Comparing Effectiveness and Engagement of Data Comics and Infographics," in CHI 2019, May 4-9, 2019 (Glasgow, UK). doi:10.1145/ 3290605.3300483

Wertham, F. (1954). Seduction of the Innocent. New York: Rinehart Company.

The Royal Society (2011). Knowledge, Networks and Nations: Global scientific collaboration in the 21st century. London: The Royal Society. .

Zamora, L. P., Bravo, S. S., and Padilla, A. G. (2021). Production of Comics in Powtoon as a Teaching-Learning Strategy in an Operations Research Course. Eur. J. Contemp. Educ. 10, 137-147. doi:10.13187/ejced.2021.1.137

Zhao, Z., Marr, R., and Elmqvist, N. (2015). "Data Comics: Sequential Art for DataDriven Storytelling," in HCIL Technical Report HCIL-2015-15 (College Park: University of Maryland), 1-12.

Conflict of Interest: The authors declare that the research was conducted in the absence of any commercial or financial relationships that could be construed as a potential conflict of interest.

Publisher's Note: All claims expressed in this article are solely those of the authors and do not necessarily represent those of their affiliated organizations, or those of the publisher, the editors, and the reviewers. Any product that may be evaluated in this article, or claim that may be made by its manufacturer, is not guaranteed or endorsed by the publisher.

Copyright (c) 2021 Robin, Leblanc and Dumais. This is an open-access article distributed under the terms of the Creative Commons Attribution License (CC $B Y)$. The use, distribution or reproduction in other forums is permitted, provided the original author(s) and the copyright owner(s) are credited and that the original publication in this journal is cited, in accordance with accepted academic practice. No use, distribution or reproduction is permitted which does not comply with these terms. 